DOI: 10.18413/2313-8912-2018-4-1-49-62

\title{
MICRO AND MACRO TYPOLOGICAL FEATURES OF THE MORPHOLOGY OF THE TURKISH LANGUAGE: CONFLICTING VIEWS BETWEEN WALS DATABASE AND NON-WALS DATABASE
}

\author{
Institute of International \& Comparative Educationб \\ Faculty of Education, Beijing Normal University (BNU), Beijing, P.R. China \\ E-mail: ibnalduais@gmail.com
}

\begin{abstract}
Typology of morphology can be examined in terms of certain features e.g. fusions, exponence, inflectional synthesis, locus, affixation, reduplication, syncretism, etc. or with broader typological features like multifunctional inflectional features, compounding, genitive construction, etc. We refer to the former as macro level features of the typology of morphology of the Turkish language with reference to data presented from WALS database and we refer to the latter as micro level of the typology of morphology of the Turkish language with references to some linguists and researchers in the field of morphology. This two-folded presentation brings about an argument about the possible limitation of the WALS database as claimed and argued by the presented views - assuming contradicting conclusions about some typological features of morphology of the Turkish language.
\end{abstract}

Key words: language typology; morphology typology; Turkish language.

\section{Introduction}

Generally speaking, languages can be approached from different perspectives. When approaching typology of languages, for instance, this area could be even restricted to a certain linguistic component i.e. phonology, morphology, word order. Typology of morphology which is our concern can be examined in terms of certain features e.g. fusions, exponence, inflectional synthesis, locus, affixation, reduplication, syncretism, etc.. A major reference and source for this purpose is the online database and studies provided

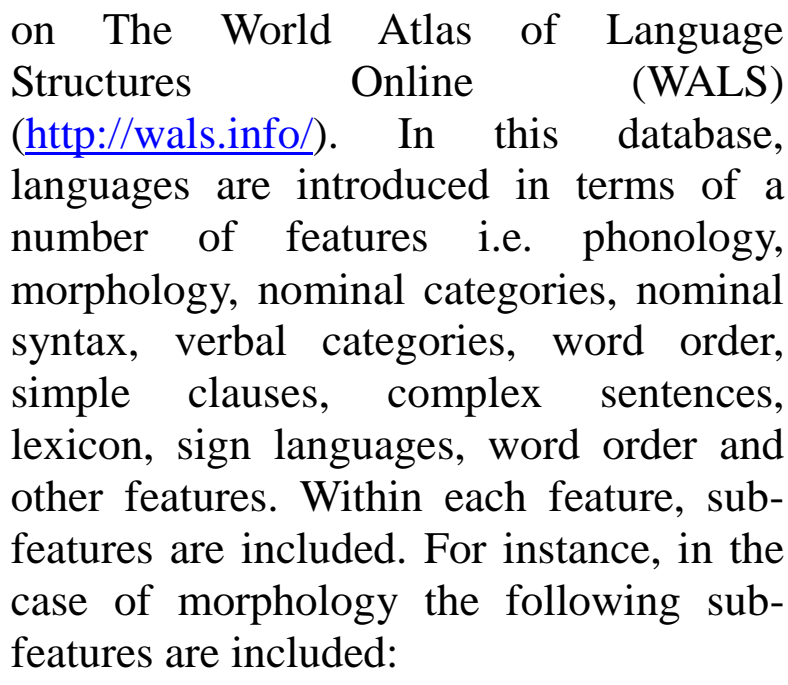


Table 1: Morphology sub-features according to WALS

\begin{tabular}{l} 
Feature \\
1. Fusion of Selected Inflectional Formatives \\
\hline 2. Exponence of Selected Inflectional Formatives \\
3. Exponence of Tense-Aspect-Mood Inflection \\
\hline 4. Inflectional Synthesis of the Verb \\
\hline 5. Locus of Marking in the Clause \\
6. Locus of Marking in Possessive Noun Phrases \\
\hline 7. Locus of Marking: Whole-language Typology \\
\hline 8. Zero Marking of A and P Arguments \\
9. Prefixing vs. Suffixing in Inflectional Morphology \\
\hline 10. Reduplication \\
11. Case Syncretism \\
12. Syncretism in Verbal Person/Number Marking
\end{tabular}

The database in generally presented in terms of features for each language component i.e. morphology or another linguistic aspect i.e. nominal categories. The total included features are 192 of which 12 are related to morphology as listed above. For detailed discussion of these features, a reader can go check the chapters' section which includes 151 chapters of which 10 are related to morphology as shown in the table below.

\section{Table 2: Morphology related chapters according to WALS}

\begin{tabular}{l} 
Chapter's title \\
1. Fusion of Selected Inflectional Formatives \\
2. Exponence of Selected Inflectional Formatives \\
3. Inflectional Synthesis of the Verb \\
\hline 4. Locus of Marking in the Clause \\
\hline 5. Locus of Marking in Possessive Noun Phrases \\
\hline 6. Locus of Marking: Whole-language Typology \\
\hline 7. Prefixing vs. Suffixing in Inflectional Morphology \\
8. Reduplication \\
9. Case Syncretism \\
10. Syncretism in Verbal Person/Number Marking \\
\hline
\end{tabular}

The database represents data for 2.679 languages. In spite of the fact that all these languages have not been included in all features and chapters but it seems that the database is a long-term project where in any related studies are continuously included. The references section provides the reader with a list of all the consulted reference where in a list of 7.374 is included. The authors' section is also another valuable feature in this database where 55 authors are listed where in the contributed articles and/or chapters are matched to each author.

Several studies argue against the practicality of the conclusions stated on 
this database. For instance, Uzun (2012a) who argues against the significant of the reliability and validity of WALS database, builds his argumentation on the basis of some statistical typology presented on WLAS. He approaches this issue with reference to other terms i.e. typicality, typology of languages, typological consistency. More interestingly, the author proposes that there are many factors that have not been taken into consideration and could affect the inferred conclusions and judgments in regard to each language. In addition to the consistency, the recency of included resources and conducted studies about each language could also affect such results and result into some changes different from those included in WALS. The author concludes his review with the idea that WALS could be a good start towards building a better typology database of the world languages.

That being said, the author intends to account for a number of typological morphological issues of the Turkish language based on the WALS database as listed in the following table.

\section{Table 3: Typological morphology features of Turkish}

\begin{tabular}{ll}
\hline Features & Characteristic \\
\hline Fusion of Selected Inflectional Formatives & Exclusively concatenative \\
\hline Exponence of Selected Inflectional Formatives & Monoexponential case \\
\cline { 2 - 2 } & Monoexponential TAM \\
\hline Inflectional Synthesis of the Verb & $6-7$ categories per word \\
\hline Locus of Marking in the Clause & Dependent marking \\
\hline Locus of Marking in Possessive Noun Phrases & Double marking \\
\hline Locus of Marking: Whole-language Typology & Inconsistent or other \\
$\begin{array}{l}\text { Prefixing vs. Suffixing in Inflectional } \\
\text { Morphology }\end{array}$ & Strongly suffixing \\
\hline Reduplication & \\
\hline Case Syncretism & Productive full and partial reduplication \\
\hline Syncretism in Verbal Person/Number Marking & Not syncretism \\
\hline
\end{tabular}

\section{Fusion in Turkish}

Fusion which refers to "the degree to which grammatical markers ... are phonologically connected to a host word or stem'. It has 'three basic values: isolating, concatenative, and nonlinear' Bickel and Nichols (2013). According to Bickel and Nichols (2013), in fusion, languages could be classified in terms of the given values below. 
Table 4: Turkish category in fusion based on WALS

\begin{tabular}{l|l}
\hline Value & Turkish \\
\hline Exclusively concatenative & $\circ$ \\
\hline Exclusively isolating & \\
\hline Exclusively tonal & \\
\hline Tonal/isolating & \\
\hline Tonal/concatenative & \\
\hline Ablaut/concatenative & \\
\hline Isolating/concatenative &
\end{tabular}

According to this table, Turkish is shown as an exclusively concatenative language in terms of fusion. Actually, there are a number of aspects that has to be taken into consideration when examining fusions. For instance, degree of fusion, phonology consistency in terms of segmental and suprasegmental features, similarity degree and linguistic distance. The following are examples for these aspects in Turkish:

\section{[1] Arabam [my car] \\ [2] Arabamız [our car]}

In the second example, $[-\mathrm{m}]$ indicates singularity for $1^{\text {st }}$ person and [-1z] indicates plurality. In other words, in the same item, we have both singular marker and plural marker. In the two following examples also, the plural of the two words is constructed following phonological consistency of the sounds.

\section{[3] Ev- evler}

Kitap- kitaplar [book-books]

Having mentioned Turkish in terms of fusion as an exclusively concatenative language, consider the examples below:

[4] Geliyorum $\rightarrow$ singular [-um] [I am coming.]
[5] Geliyoruz $\rightarrow$ plural [-uz] [We are coming.]

[6] Geliyorlar $\rightarrow$ plural [-lar] [They are coming.]

[7] Gel $\rightarrow$ [-zeor morph] [Come $\left.{ }^{\text {verb }}\right]$

[8] Gelsin $\rightarrow$ [-sin] [Come!]

There are actually many aspects that could be investigated in Turkish in this regard. Consider the following examples:

[9] Onun arabisini as compared to onun arabas1 [hid car]

[10] Tren ile as compared to trenle (full and short forms) [by train, with a train]

[11] The deletion of $/ r /$ at the end of word like (Geliyor [s/he is coming.], Bekliyor [s/he is waiting.], to be pronounced as [nasalised /o:/] etc.)

Uzun (2012b) argues in favour of a new proposal that could offer a more accurate ranking of languages in terms of their typology. The author starts his proposal with a presentation for the used assessing method on WALS. According to the author, WALS has been based on typology, typicality and consistency of languages. Having this in mind, the author uses the same database presented on WALS to shown that using the features of similarity and difference frequency among languages could results to more accurate 
results ranking languages in terms of their consistency and typicality.

\section{Fusion and Exponence in Turkish}

The second typological morphology feature is exponence. According to Bickel and Nichols (2013), it refers to 'the number of categories that cumulate into a single formative'. Within this feature, the following values are possible.

Table 5: Turkish Language category in exponence feature based on WALS

\begin{tabular}{l|l} 
Value & Turkish \\
\hline Monoexponential case & $\circ$ \\
\hline Case + number & \\
\hline Case + referentiality & \\
\hline Case + TAM (tense-aspect-mood) & \\
\hline No case &
\end{tabular}

Table 6: Turkish Language category in exponence feature based on WALS

\begin{tabular}{l|l} 
Value & Turkish \\
\hline monoexponential TAM & 0 \\
\hline TAM+agreement & \\
\hline TAM+agreement+diathesis & \\
\hline TAM+agreement+construct & \\
\hline TAM+polarity & \\
\hline no TAM &
\end{tabular}

The first table shows exponence of Turkish in terms of case exponence as monoexponential. The second table present exponence in terms of TenseAspect-Mode (TAM) where Turkish is categorised as TAM monoexponential. In general, the following examples illustrate exponence in Turkish.

[12] $1 \mathrm{Ar} \rightarrow$-lara (dative)

[13] $1 \mathrm{Ar} \rightarrow$-lere (dative)

[14] $1 \mathrm{Ar} \rightarrow$-leri (accusative)

[15] $1 \mathrm{Ar} \rightarrow$-larından (ablative)

[16] $1 \mathrm{Ar} \rightarrow$-lerinden (ablative)

[17] Kitap (+ referenced) [book]

[18] Kitab1 (- referenced) [e.g. the/that book]

Consider also these examples in terms of definite and indefinite accusative:
[19] Ben eve gidiyorum. [I am going home.]

[20] $\mathrm{O}$ eve gidiyorum. [He is going home.]

[21] Evime gidiyorum. [I am going my home.]

More example in terms of part-all is:

[22] Yemeği yedim. (all) [I had/ate the food.]

[23] Yemek yedim. (some) [I had/ate something.]

\section{Inflectional Synthesis, Locus, Affixation, Reduplication and Syncretism}

To start with synthesis, it refers to the addition and/or use of an affix or a word to a certain grammatical category i.e. 
tense, voice, agreement (Bickel \& Nichols, 2013). Furthermore, synthesis can be either synthetic i.e. attaching an affix (English: walk-ed) or analytic i.e. adding a separate word (English: will walk) (ibid). The following value are used on WALS to shown the representation of Turkish in terms of inflectional synthesis.

\section{Table 7: Turkish Language category in synthesis feature based on WALS}

\begin{tabular}{|l|l|}
\hline Value & Turkish \\
\hline $0-1$ category per word & \\
\hline $2-3$ categories per word & \\
\hline $4-5$ categories per word & \\
\hline $6-7$ categories per word & $\circ$ \\
\hline 8-9 categories per word & \\
\hline $10-11$ categories per word & \\
\hline $12-13$ categories per word &
\end{tabular}

According to this table, Turkish is shown within the 6-7 categories per word. This seems to be the default structure for Turkish. However, 8-9 categories per words seems to be possible according to the following example.

[24] Ev-ler ${ }^{1}-\mathrm{im}^{2}-\mathrm{iz}^{3}-\mathrm{de}^{4}-\mathrm{ki}^{5}-l e \mathrm{r}^{6}-\mathrm{in}^{7}-$ $\mathrm{iz}^{8}-\mathrm{den}^{9}$
In spite of this, it should be noted that sometimes not all attachments are to be counted. For instance, (-me) [used for making negative] is not to be counted.

[25] Gelecek Gelmeyecek [-will come/ will not come]

Consider also the following detailed example.

Table 8: Detailed example of primary and secondary suffix in Turkish

\begin{tabular}{llll}
\hline Main suffix & \multicolumn{4}{l}{ Secondary suffix } \\
\hline -yor & $\varnothing \quad-m \quad$ uz & sun & Sunuz \\
\hline -du & -im & -dik & \\
\hline -miş & & & \\
\hline -1r & & & \\
\hline -mal1 & & & \\
\hline -se & gel- $\emptyset-\emptyset$ & & \\
\hline -e & Gelsin & & \\
\hline$-\varnothing$ & & & \\
\hline
\end{tabular}

Having accounted for inflectional synthesis, now we will move to locus. Locus is going to be presented in terms of three aspects according to the WALS database: 1) locus of marking in the clause, 2) locus of marking in possessive noun phrase and 3) locus of marking in whole language typology.

Basically locus is represented through 'in any kind of phrase, overt morphosyntactic marking reflecting the syntactic relations within the phrase may 
be located on the head of the phrase, on a non-head (i.e. on a dependent), on both, or on neither' (Nichols and Bickel 2013). In this case, languages could be categorised in terms of the given values below. Turkish is within the dependent-marked category.

Table 9: Turkish Language category in locus feature based on WALS

\begin{tabular}{l|l} 
Value & Turkish \\
\hline $\mathrm{P}$ is head-marked & \\
\hline $\mathrm{P}$ is dependent-marked & $\circ$ \\
\hline $\mathrm{P}$ is double-marked & \\
\hline $\begin{array}{l}\mathrm{P} \text { has no marking } \\
\text { Other types }\end{array}$ &
\end{tabular}

The second type of locus is that of marking in possessive nouns phrases. In this type also, five values could be used to categorise languages. In this type, Turkish changes to the double-marked category. Consider the following examples.
[26] Benim ${ }^{1}$ güzel evim² ${ }^{2} \rightarrow$ double marking [my beautiful my house*]

[27] Ben $\emptyset^{0}$ evi gördüm ${ }^{1}$. [I saw the house.]

[28] Benim ${ }^{1}$ evim gördüm ${ }^{2}$. $\rightarrow$ doublemarking [I saw my house.]

\section{Table 10: Turkish Language category in marked locus feature based on WALS}

\begin{tabular}{l|l} 
Value & Turkish \\
\hline Possessor is head-marked & \\
\hline Possessor is dependent-marked & \\
\hline Possessor is double-marked & $\circ$ \\
\hline Possessor has no marking & \\
\hline Other types &
\end{tabular}

One more type of locus is that of whole-language typology. In this case, two types of values are given: first in the case of whole-language typology and then in the case of zero-marking of $\mathrm{A}$ and $\mathrm{B}$ arguments. The following two tables illustrates such values. In the former, Turkish has the feature of inconsistent marking or other types. In the second case of $\mathrm{A}$ and $\mathrm{B}$ arguments, it has the non-zero marking value.

Table 11: Turkish Language category in locus feature based on WALS

Value Turkish

Consistently head-marking

Consistently dependent-marking

Consistently double-marking

Consistently zero-marking

Inconsistent marking or other type 
Table 12: Turkish Language category in locus feature based on WALS

\begin{tabular}{l|l} 
Value & Turkish \\
\hline Zero-marking & \\
\hline Non-zero marking & $\circ$
\end{tabular}

The next typological morphology categorising languages in regard to this aspect is affixation i.e. prefixing vs. suffixing in inflectional morphology. aspect. Turkish is among the Dryer (2013) used a number of values for predominantly suffixing languages.

Table 13: Turkish Language category in marked prefixing and suffixing feature based on WALS

\begin{tabular}{|l|l|}
\hline Value & Turkish \\
\hline Little or no inflectional morphology & \\
\hline Predominantly suffixing & $\circ$ \\
\hline Moderate preference for suffixing & \\
\hline Approximately equal amounts of suffixing and prefixing & \\
\hline Moderate preference for prefixing & \\
\hline Predominantly prefixing &
\end{tabular}

Another typological morphology aspect is reduplication which refers to 'the repetition of phonological material within a word for semantic or grammatical purposes is known as reduplication, a widely used morphological device in a number of the world's languages' (Rubino, 2013). Three values are given in this regard as shown below. Turkish is among the productive full and partial republication. Consider the following examples.

[29] bembeyaz [snow/extremelywhite]

[30] sapsar1 [bright yellow]

Table 14: Turkish Language category in marked reduplication feature based on WALS

\begin{tabular}{l|l} 
Value & Turkish \\
\hline Productive full and partial reduplication & $\circ$ \\
\hline Full reduplication only & \\
\hline No productive reduplication &
\end{tabular}

The last typological morphology aspect according to WALS is syncretism which could be presented in terms of: case syncretism and syncretism in verbal person and number marking. Four values are established in the first case as shown in the table below. In the second case, three values are established. In both cases,
Turkish as categorised as non-syncretic. This could be attributed to the explanation that languages which are characterised as pro-drop ones are non-syncretic as in the case of Turkish. On the other hand, languages which are marked as non-prodrop languages, are considered as syncretic languages e.g. English. 
Table 15: Turkish Language category in marked syncretism feature based on WALS

Value

Turkish

Inflectional case marking is absent or minimal

Inflectional case marking is syncretic for core cases only

Inflectional case marking is syncretic for core and non-core cases

Inflectional case marking is never syncretic

Table 16: Turkish Language category in marked syncretism feature based on WALS

Value

Turkish

No subject person/number marking

Subject person/number marking is syncretic

Subject person/number marking is never syncretic

\section{Inflectional Issues on Turkish conflicting with WLAS database}

Uzun (2015) argues against the view that Turkish adopts multifunctional inflectional affixes. His argument is mainly based on proposing an alternative approach for discussing such typological feature in Turkish. He presents the zeromorpheme along with taking into consideration pragmatic and discourse factors when accounting for such factor in Turkish. According to the author, many studies accounted for verbal inflectional affixes in Turkish and presented it as multifunctional inflectional languages where in a certain affix can have more than one function. Among these studies are those bye: Johanson (1971, 1994); Aksu-Koç (1978); Slobin and Aksu-Koç (1982); Yavaş (1980, 1982); Erguvanl1Taylan (1996); Bassarak (1994) and Kornfilt (1997). On the basis, of this, the author offers a zero-morpheme analysis for the inflectional affix in Turkish attempt to prove the opposite that each and every affix in Turkish stands by itself presenting a separate and/or [unique] function.

Further, the author presents an example from (Yavaş, 1980) quoted in Erguvanl-Taylan (1996) explaining the misinterpretation of some morphological aspects in terms of pragmatics and discourse (-ti), the tense marker functioning as mood marker. This argument continues with reference to Erguvanl1-Taylan's study (1996), the suffix (-ti) is presented in terms of two paradigms: one as a multifunctional inflectional suffix and one as a monofunctional in the case of past. The author sheds light on some problems of the multifunctional approach including the contradiction of inferred conclusions among researchers e.g. Erguvanl1-Taylan (1996) and Bassarak (1994) n regard to tense. Yet, it is shown that on the basis of previous literature like those by Tura (1986) and Kornfilt (1997) Turkish has already zero-morpheme. Evident examples for this include: (Ali burada $\emptyset$ ) [Ali is here] and (Geldim, Geldin, Geldi $\varnothing$ ) [I came., You came., S/he came.]. Having this in mind, it seems to be possible according to author to dive into other aspects of tense-mood-aspect toward zeromorpheme analysis. The two suffixes (-TI) and (-(I)yor) are presented as [-perfective and + continuous] for the former and [+perfective and -continuous] for the latter-replicating the view that a tensemarker functioning as mood-marker. Similarly, (-AcAk) and (-Ir) are presented as [-perfective and -continuous] to 
replicate the view that they are neither affixes of tense nor affixes of aspect; mood (presented through zero-morphemes each)! This applied also to the past affix (-TI) which is presented as [+past and past] replicating the presented paradigms as multifunctional and mono-functional. The author also mentioned the zeromorpheme of mood presented as [-subjunctive $(\varnothing)$ and +subjunctive (others)] and the adverbs' case which according to him not only interacts with tense but also with aspect and mood.
Besides, (-mIș) is presented as [-subjunctive and +evidential], a moodmarker.

\section{Compounding and genitive construction in Turkish}

Theoretically, two views could be presented in regard to compounding and genitive possessive construction: transformational and lexical. In general sources of Turkish grammar, compounding and possessive construction are illustrated with examples as it follows:

\begin{tabular}{lll}
\hline Form & Example & English meaning \\
\hline Adjective+ noun & Paralı okul & Self-funded school \\
\hline Noun+ noun+ possessive & Yol parası & Toll \\
\hline Noun+ noun & Süt nine & Foster-nurse \\
\hline Nouns+ possessive+ noun+ possessive & Arabanın boyas1 & The car's paint \\
\hline
\end{tabular}

In the case of collocations, a continuous possessive construction is possible, e.g. hava gazı sayac1 and hava gazı sayaç kapak vidası. Acceptability is also another feature that could be found during compounding and genitive constructions. Consider the following examples: duvar boyası, aslan ağzı, duvar boyaları, aslan ağızları, duvarın boyası, but not aslanın ağzı.

Moreover yet linguistically, phonological, phonetic, semantic and syntactic effects could also affect compounding and genitive possessive construction. In the case of phonetics for instance, consider the words: Cumartesi
(Cuma-ertesi) and kahvaltı (kahve-altı). In phonology, consider the stress which could mark compounding and genitive possessive construction in example like: kötü talih and kara yazı. Or, this affect could be in terms semantic compositionality. Consider the following three examples which present three different functions semantically: ateş böceği, su çiçeği and öğle yemeği.

Furthermore, compounding and genitive possessive construction can be approached using semantic-syntactic bases. Consider this example: sandik cinayeti ( $\mathrm{N}+\mathrm{N}+$ Poss.). Consider the following semantic-based constructions:

[31] süt nine [foster-nurse: raised by a nurse of someone else]

[32] süt baba [foster father: not real father, but raised by]

[33] süt anne [foster mother: not real mother, but raised by]

[34] süt oğul [foster son: not real son, raised by]

[35] süt k1z1 [foster daughter: not real daughter, raised by]

[36] süt kardeş [foster brother: not real brother, raised with]

Finally and with reference to (Sezer, 1982) compounding and genitive possessive construction can be approached in terms of reduction, deletion and action of interest. Consider the following examples where all constructions seem acceptable: 
Table 17: Compounding examples in Turkish

\begin{tabular}{ll}
\hline Examples & \\
Kitap pahalı & Adamın parası var \\
kitabın pahalı OLması & adamın parasının OLması \\
pahalı OLan kitap & parası OLan adam \\
pahalı kitap & paraLi adam \\
\hline
\end{tabular}

Comparatively, consider the following seems unacceptable: constructions where the last in each

\begin{tabular}{ll}
\hline Example & \\
Ali'nin evi var & Ali'nin k1zı var \\
Ali'nin evinin OLması & Ali'nin k1zı OLması \\
evi OLan Ali & k1zı OLan Ali \\
*evli Ali & ?kıLl Ali \\
\hline
\end{tabular}

Compounding formation based on hypothetical views e.g. sentence formation and word formation, strict lexical hypothesis and level ordering hypothesis (Uzun, 1994). Four types of compounding could be introduced:

Table 18: Compounding types in Turkish

\begin{tabular}{ll}
\hline Form & Example \\
Noun compounding & baba yiğit \\
Adjective compounding & alçak gönüllü \\
Adverb compounding & en aşağı \\
Verb compounding & geliver-! \\
\hline
\end{tabular}

Consider also the following examples:

Table 19: More examples of compounding in Turkish

\begin{tabular}{|c|c|}
\hline Form & Example \\
\hline \multirow[t]{3}{*}{$+\mathrm{sI}$} & gözü kara \\
\hline & gözü tok \\
\hline & gözü pek \\
\hline \multirow[t]{3}{*}{$+\mathrm{tAn}$} & baştan kara \\
\hline & baştan savma \\
\hline & kulaktan dolma \\
\hline \multirow[t]{3}{*}{$+\mathrm{tA}$} & çantada keklik \\
\hline & denizde balık \\
\hline & devede kulak \\
\hline$+(\mathrm{y}) \mathrm{A}$ & içe bakış \\
\hline & $\begin{array}{l}\text { içe kapanık } \\
\text { ice donuk }\end{array}$ \\
\hline & \\
\hline
\end{tabular}


Compounding in Turkish could be viewed and approached differently overpassing the classic views of compounding on Turkish. Three approaches are possible to achieve this (Uzun, 1994):

Table 20: Proposed approaches to study compounding in Turkish according to (Uzun, 1994)

\begin{tabular}{ll}
\hline Approach & Example \\
Ending with two depended bases & [hasır [şapka]] \\
Attaching hypothetical base at the end & söz dizim[-i] \\
Attaching a discrete hypothetical base & sahan [-da] yumurta
\end{tabular}

Corpus-based and Data-based Morphology

Productivity and frequency, productivity areas, and possible restrictions are some areas of typology of the morphology of Turkish. (Uzun, 2006) reported the most frequently used derivations and their frequency status according to different sources i.e. (+lIk, + II, +ÇI, +IA-, +sIz). The same affixes can have different frequency order changing into $(2,4,3,5,1)$. This argument is mainly based on Aronoff's views on word formation (1976). Moreover, according to Baayen's approach (1991), this order of frequency could change into something like $(5,3$,

Table 21: Productivity areas presentation

\begin{tabular}{l}
\hline Productivity areas \\
\hline Type based area \\
\hline Production type area \\
\hline Semantic fucntion area \\
\hline
\end{tabular}

Table 22: Productivity measuring features in Turkish

\begin{tabular}{ll} 
Productivity measuring features \\
\hline Type-base \\
\hline Structure-base \\
\hline Origin \\
\hline Derivation-base \\
\hline Neologisms \\
\hline
\end{tabular}

2, 4, 1), according to morphological productivity measure i.e. $\mathrm{P}=\mathrm{n}_{1} / \mathrm{N}$. Again, we would have a different frequency order according to the derivational productivity measure proposed by Bauer (2001) resulting into something like $(2,4,3,5,1)$. The author presented the average frequency of these affixes by taking by converting the average of all these measures to have something like $(4,3,2$, $1,2)$. In the first area, for instance, word classes are presented where nouns, adjectives, verbs and other classes appear in order according to their frequency. Productivity can be presented as shown below below. 
Verb classes with reference to Levin's hypothesis to the study of verb classes was also approached by (Uzun, 2003). The author raises an argument of verb classes alternation claiming that the application of this approach on other languages, other than English - which Levin used to support her arguments. Consider for instance the following example in English:

[37] I cut the bread with this knife.

[38] This knife cut the bread.

[39] This knife doesn't cut.

$\uparrow$

cut $\rightarrow$ action is performed by the subject I

cut $\rightarrow$ action is performed by the knife as a tool for cutting

cut $\rightarrow$ action is referred to the ability of the tool to cut or do something!

According to Levin, semantic alternations in the verb cut resulted into change of semantic behaviour in the verb cut. This is exactly, what Uzun attempted on in his article with more emphasis on the alternation within a certain verb among languages i.e. Turkish and English.

\section{Conclusions}

Typology of languages, namely Turkish, yet specifically, morphology includes many features and aspects. While the WALS database presents a semicomprehensive framework for these aspects and features - putting into action the efforts of the authors supporting their database, other linguists and researchers might look at the typology of morphology deeper than that being approached on the WALS database. Given that, the typological features of morphology seem to have macro and micro levels. The first represents those general aspects listed in tables 1 and 2 and some more others and the second could represent those very specific features that can be found within certain dialects, idiolects, variations of within the same language as presented by Uzun and other researchers in the case of the Turkish Language.

Информация о конфликте интересов: авторы не имеют конфликтов интересов для деклараџии.

Information of conflict of interests: authors have no conflicts of interests to declare.

\section{References}

1. Baerman, M., \& Brown, D. (2013), Case Syncretism, Retrieved April 3, 2016, from The World Atlas of Language Structures [Online], Leipzig: Max Planck Institute for Evolutionary Anthropology, Available at: http://wals.info/chapter/28

2. Baerman, M., \& Brown, D. (2013), Syncretism in Verbal Person/Number Marking, Retrieved April 3, 2016, from The World Atlas of Language Structures [Online], Leipzig: Max Planck Institute for Evolutionary Anthropology, Available at: http://wals.info/chapter/29

3. Bickel, B., \& Nichols, J. (2013), Exponence of Selected Inflectional Formatives, Retrieved April 3, 2016, from The World Atlas of Language Structures [Online], Leipzig: Max Planck Institute for Evolutionary Anthropology, Available at: http://wals.info/chapter/21

4. Bickel, B., \& Nichols, J. (2013), Fusion of Selected Inflectional Formatives, Retrieved April 3, 2016, from The World Atlas of Language Structures [Online], Leipzig: Max Planck Institute for Evolutionary Anthropology, Available at: http://wals.info/chapter/20

5. Bickel, B., \& Nichols, J. (2013), Inflectional Synthesis of the Verb, Retrieved April 3, 2016, from The World Atlas of Language Structures [Online], Leipzig: Max Planck Institute for Evolutionary Anthropology, Available at: http://wals.info/chapter/22

6. Dryer, M. S. (2013), Suffixing in In- 
flectional Morphology, Retrieved April 3, 2016, from The World Atlas of Language Structures [Online], Leipzig: Max Planck Institute for Evolutionary Anthropology, Available at: http://wals.info/chapter/26

7. Dryer, M. S., \& Haspelmath, M. (Eds.). (2013), The World Atlas of Language Structures [Online], Retrieved May 1, 2016, from Leipzig: Max Planck Institute for Evolutionary Anthropology, Available at: http://wals.info

8. Nichols, J., \& Bickel, B. (2013), Locus of Marking in Possessive Noun Phrases, Retrieved April 3, 2016, from The World Atlas of Language Structures [Online], Leipzig: Max Planck Institute for Evolutionary Anthropology, Available at: http://wals.info/chapter/24

9. Nichols, J., \& Bickel, B. (2013), Locus of Marking in the Clause, Retrieved April 3, 2016, from The World Atlas of Language Structures [Online], Leipzig: Max Planck Institute for Evolutionary Anthropology, Available at: http://wals.info/chapter/23

10. Nichols, J., \& Bickel, B. (2013), Locus of Marking: Whole-language Typology, Retrieved April 3, 2016, from The World Atlas of Language Structures [Online], Leipzig: Max Planck Institute for Evolutionary Anthropology, Available at: http://wals.info/chapter/25

11. Rubino, C. (2013), Reduplication, Retrieved April 3, 2016, from The World Atlas of Language Structures [Online], Leipzig: Max Planck Institute for Evolutionary Anthropology, Available at: http://wals.info/chapter/27
12. Uzun, N. E. (1990), Türkçe dîlbîlgîsînde 'Tamlama' Ve 'Bileştk' sorunu. IV. Dilbilim Sempozyumu bildirileri: 17-18. [in Turkish].

13. Uzun, N. E. (1994), Türkçede Bileşiğin Biçimlenişi: Varsayımsal taban yaklaşımıyla yeni bir sinıflama. Dilbilim Araştırmaları, 128-140. [in Turkish].

14. Uzun, N. E. (2003), Levin 1993'ün Sözlüksel Üye Değiştirimleri: Türkçe Üzerine Bir Deneme, Günümüz Dilbilim Çalışmaları, 98-120. [in Turkish].

15. Uzun, N. E. (2006), Türetim eklerinin türetkenliğini ölçme önerileri üzerine. XX. Dilbilim kurultayı bildirileri, 147-159. [in Turkish].

16. Uzun, N. E. (2015), A New Analysis for Verbal Inflectional Affixes in Turkish, International Journal of Foreign Studies, 8(1), 39-62.

17. Uzun, N. E. (2012a), "Wals Yapabilir miyiz?": 26. Ulusal Dilbilim Kurultayı Bildirileri, 24-26 Mayls 2012, Yay.: Baykal, N. ve K. Büyükkarc1, G. Ulusoy, Süleyman Demirel Üniversitesi Yayını, Isparta. [in Turkish].

18. Uzun, N. E. (2012b), "WALS-tabanlı Tipolojik Siralamalar İçin Bir Öneri": 16. Uluslararası Türk Dilbilim Kurultayl 18-21 Eylül, Middle East Technical University, Ankara. [in Turkish].

Ahmed Alduais, Institute of International \& Comparative Education, Faculty of Education, Beijing Normal University (BNU). 